\title{
PERMAINAN TRADISIONAL KAULINAN BARUDAK UNTUK MENGEMBANGKAN KEMAMPUAN MENGELOLA EMOSI DIRI SENDIRI ANAK USIA DINI
}

\author{
Ahmad Mulyadiprana ${ }^{1}$, Nana Ganda ${ }^{2}$, Rustono WS \\ ${ }^{1}$ Universitas Pendidikan Indonesia Kampus Tasikmalaya \\ ${ }^{2}$ Universitas Pendidikan Indonesia Kampus Tasikmalaya \\ ${ }^{3}$ Universitas Pendidikan Indonesia Kampus Tasikmalaya \\ Email: ahmadmulyadiprana@upi.edu
}

(Received: September 2017; Accepted: Oktober 2017; Published: Desember 2017)

\begin{abstract}
This research is based on the facts in the field regarding the process of achieving early childhood education that is not optimal. Eeducational attainment is about to manage sel emotion of early childhood. The traditional games "kaulinan barudak" are one of the learning process approaches could be expected to provide positive stimulation toward developmental aspect of children's potential. This study is conducted to determine the contribution of traditional games "kaulinan barudak" to the development of self emotion manage of children aged 5-6 years. This study uses quasi-experimental method with Pretest and Posttest control group design. Data is collected using structured observation, notes, and documentation. The results of this study are 1) the ability of self emotion manage of children aged 5-6 years in kindergarten Artanita Tasikmalaya entered into category"positive significant"; 2) the ability of self emotion manage of children aged 5-6 years of conventional game in kindergarten Artanita Tasikmalaya entered into category"no siginificant positive effect"; 3) the ability of self emotion manage of children aged 5-6 years in kindergarten Artanita Tasikmalaya entered into category"Different effect of traditional game "kaulinan barudak" from the conventional game". The traditional game of "kaulinan barudak" gives a more significant positive effect than the conventional game.
\end{abstract}

Keywords: Traditional Games "Kaulinan Barudak", Self Emotion Manage, Early Childhood.

\begin{abstract}
ABSTRAK
Penelitian ini dilatarbelakangi oleh fakta-fakta di lapangan mengenai kondisi proses pencapaian pendidikan anak usia dini yang belum optimal. Proses pencapaian pendidikan yang dimaksud adalah kemampuan mengelola emosi diri sendiri anak usia dini. Permainan tradisional "kaulinan barudak" merupakan salah satu pendekatan proses belajar yang diduga dapat memberikan stimulasi positif terhadap aspek perkembangan potensi anak. Penelitian ini dilakukan untuk mengetahui kontribusi permainan tradisional "kaulinan barudak" terhadap pengembangan kemampuan mengelola emosi diri sendiri anak usia 5-6 tahun. Penelitian ini menggunakan metode kuasi eksperimen dengan Pretest-Posttest control group design. Teknik pengumpulan data menggunakan observasi terstruktur, catatan lapangan dan dokumentasi. Hasil penelitian menunjukkan bahwa 1) Terdapat pengaruh yang positif dan signifikan penerapan permainan tradisional kaulinan barudak terhadap pengembangan kemampuan mengelola emosi diri sendiri anak usia 5-6 tahun di TK Artanita Kota Tasikmalaya; 2) Tidak terdapat pengaruh positif yang signifikan penerapan permainan konvensional terhadap pengembangan kemampuan mengelola emosi diri sendiri anak usia 5-6 tahun di TK Negeri Pembina Kota Tasikmalaya; 3) Terdapat perbedaan pengaruh permainan tradisional kaulinan barudak dengan permainan konvensional terhadap pengembangan kemampuan mengelola emosi diri sendiri anak usia 5-6 tahun. Permainan tradisional kaulinan barudak memberikan pengaruh positif yang lebih signifikan dari pada permainan konvensional.
\end{abstract}

Kata Kunci: Permainan Tradisional "Kaulinan Barudak", Kemampuan Mengelola Emosi Diri Sendiri, Anak Usia Dini.

\section{PENDAHULUAN}

Berdasarkan Undang-Undang Nomor 20 Tahun 2003 tentang Sistem Pendidikan Nasional berkaitan dengan dengan Pendidikan Anak Usia Dini tertulis pada pasal 2 ayat 1 yang berbunyi "Pendidikan Anak Usia Dini diselenggarakan bagi anak sejak lahir sampai dengan enam tahun dan bukan merupakan prasyarat untuk mengikuti pendidikan dasar." Perkembangan setiap karakteristik anak usia dini cenderung dipengaruhi oleh sentuhansentuhan secara fisik maupun psikis dari lingkungan hidupnya. Konteks itu dikuatkan oleh Geldard \& Geldard (2012) bahwa 
lingkungan merupakan bagian terbesar dalam mempengaruhi perubahan perilaku setiap anak. Berdasarkan teori tersebut, dapat diartikan bahwa lingkungan merupakan aspek terbesar dan dapat memberikan pengaruh terhadap perkembangan anak.

Berdasarkan hasil studi lapangan, tepatnya di TK Artanita Kota Tasikmalaya dan di TK Negeri Pembina Kota Tasikmalaya menyatakan bahwa terdapat beberapa hal yang dapat dinyatakan sebagai persoalan yang berkaitan dengan pencapaian proses pendidikan anak usia dini, antara lain yaitu kemampuan mengelola emosi sendiri yang merupakan kompetensi dasar yang diharapkan dimiliki anak agar kedepannya mereka lebih siap melanjutkan pendidikan ke jenjang berikutnya serta dapat menjalani kehidupannya dengan cenderung lebih baik. Persoalan tersebut perlu dilakukan penyelesaian secara cepat. Persoalan terkait kemampuan mengelola emosi diri sendiri anak usia 5-6 tahun di TK Artanita Kota Tasikmalaya dan di TK Negeri Pembina Kota Tasikmalaya terlihat belum optimal. Kemudian persoalan lain terkait stimulus guru dalam memfasilitasi kegiatan belajar anak usia 5-6 tahun di TK Artanita Kota Tasikmalaya dan di TK Negeri Pembina Kota Tasikmalaya terlihat belum berani melakukan penerapan pendekatan secara khusus di sekolah untuk mengembangkan kemampuan mengelola emosi diri sendiri anak usia 5-6 tahun.

Anak usia dini cenderung lebih dekat dengan dunia bermain. Gandana (2015) dalam penelitiannya mengugkap bahwa permainan tradisional merupakan metode yang tepat dan dapat diterapkan untuk anak usia 5-6 tahun. Oleh karena itu permainan Tradisioanal "Kaulinan Barudak" merupakan salah satu bentuk permainan yang dapat diterapkan dan dijadikan sebagai metode khusus yang diduga dapat mengembangkan kemampuan mengelola emosi diri sendiri anak usia 5-6 tahun.

\section{KAJIAN PUSTAKA}

Berbagai teori perkembangan individu diuraikan oleh Rakhmat, Budiman, \& Herawati (2008). Salah satu teori tersebut disebut dengan teori konvergensi. Teori tersebut memahami bahwa potensi yang dimiliki anak sejak lahir akan berkembang ketika dibesarkan dalam lingkungan yang mendukung. Catron dan Allen (Sujiono, 2009) menyebutkan bahwa terdapat enam aspek perkembangan anak usia dini, yaitu kesadaran personal, kesehatan emosional, sosialisasi, komunikasi, kognisi dan keterampilan motorik sangat penting dan harus dipertimbangkan sebagai fungsi interaksi. Kreativitas tidak dipandang sebagai perkembangan tambahan, melainkan sebagai komponen integral dari lingkungan bermain yang kreatif. Dalam penelitian ini penulis memfokuskan pada aspek pengembangan sikap empati dan pola gerak dasar anak usia dini.

Kemampuan anak dalam mengelola emosi dirinya sendiri dapat dilihat dari dimensi kemampuan anak dalam memanfaatkan emosi diri secara positif, kemudian kemampuan mengatur emosi sesuai dengan situasi dan kondisi diri, dan kemampuan pertahanan diri anak itu sendiri dalam berbagai bentuk posisi persoalan anak secara wajar. Kemampuan mengatur emosi sesuai dengan situasi dan kondisi dapat dimunculkan oleh anak dengan mampunya menunda kenikmatan diri dan mampu bertindak sesuai dengan keadaan. Kemampuan tersebut akan membuahkan perilaku anak seperti mau menunggu giliran atau antre bermain dengan temannya, anak membereskan alat permainan setelah selesai bermain, anak memperhatikan cara temannya bermain ketika menunggu giliran bermain, anak menggantikan posisi temannya yang tidak bisa menyelesaikan permainan, anak patuh pada instruksi guru, dan anak mematuhi atura yang telah disepakati bersama temannya. (Vakola, dkk, 2004; dan Nurhidayah, 2006).

Menurut Bishop \& Curtis dalam Iswinarti (2010, hlm 6) mengemukakan bahwa permainan tradisional merupakan suatu permainan yang telah dilakukan atau dimainkan oleh anak-anak pada suatu daerah tertentu secara tradisi dan permainan tersebut telah diwariskan dari generasi ke generasi untuk meneruskan tradisi daerah tersebut. Iswinarti (2010) yang mengemukakan terkait permainan tradisional "kaulinan barudak" dapat mengembangkan setiap aspek 
perkembangan anak, maka dapat diambil kesimpulan bahwa permainan tradisional dapat diadikan media kegiatan belajar anak. Lebih lanjut lagi Syaodih dan Agustin (2013) menyatakan tentang penerapan permainan tradisional "kaulinan barudak" untuk mengembangkan nilai karakter anak menyatakan bahwa permainan tradisional "kaulinan barudak" dapat mengembangkan nilai karakter anak usia dini. Sehingga terdapat unsur-unsur yang memberikan stimulus untuk mengembangkan potensi anak usia dini secara positif dan layak dinyatakan sebagai permainan edukatif permainan tradisional "kaulinan barudak".

\section{METODE}

Metode penelitian yang digunakan dalam penelitian ini adalah metode eksperimen untuk melihat perkembangan kemampuan mengelola emosi diri sendiri anak usia 5-6 tahun melalui permainan tradisional "kaulinan barudak". Desain penelitian yang digunakan dalam penelitian ini adalah Quasi Eksperimen dengan bentuk Non equivalent Pretest-Posttest Control Group Design. Hal tersebut merujuk kepada Creswell (2010, hlm 132) bahwa penelitian ini akan melakukan Pretest dan Posttest terhadap dua kelas anak usia 5-6 tahun untuk dilihat kemampuan mengelola emosi diri sendiri anak usia dini.

Tabel 3.1. Desain Penelitian

\begin{tabular}{cccc} 
Kelompok & Pretest & Perlakuan & Posttest \\
\hline Eksperimen & O1 & $\mathrm{X}$ & $\mathrm{O} 2$ \\
Kontrol & $\mathrm{O} 3$ & - & $\mathrm{O} 4$ \\
\hline Keterangan: & O1 : Pretest Kelompok \\
Eksperimen & O2 : Posttest Kelompok \\
Eksperimen & O3 : Pretest Kelompok Kontrol \\
O4 : Posttest Kelompok Kontrol \\
\multicolumn{3}{c}{ X : Ada Perlakuan } \\
& $-\quad$ : Tanpa Perlakuan
\end{tabular}

Subjek penelitian ini adalah anak usia dini di TK Artanita Kota Tasikmalaya sebagai kelompok eksperimen dan TK Negeri Pembina Kota Tasikmalaya sebagai kelompok kontrol. Masing-masing kelompok sampel terdiri dari
20 orang sampel. Instrumen dalam penelitian ini terdiri dari observasi terstruktur, catatan lapangan dan dokumentasi. Kisi-kisi instrumen untuk melihat kemampuan sikap empati anak usia dini menurut Gandana (2015)

\section{HASIL DAN PEMBAHASAN Deskripsi Data}

Data hasil penelitian tersebut terdiri dari beberapa kelompok data. Diantaranya data pretest (tes awal) dan posttest (tes akhir) kemampuan mengelola emosi pada kelompok eksperimen, juga data pretest dan posttest kemampuan mengelola emosi pada kelompok kontrol. Untuk memberikan gambaran mengenai data hasil penelitian, berikut ini peneliti tampilkan deskripsi data melalui Tabel 4.1.

Tabel 4.1. Deskripsi Data Hasil Penelitian

\begin{tabular}{|l|c|c|c|c|}
\hline \multirow{2}{*}{} & \multicolumn{2}{|c|}{ Pretest } & \multicolumn{2}{c|}{ Posttest } \\
\cline { 2 - 5 } & $\begin{array}{c}\text { Eksperi } \\
\text { men }\end{array}$ & $\begin{array}{c}\text { Kontr } \\
\text { ol }\end{array}$ & $\begin{array}{c}\text { Eksperi } \\
\text { men }\end{array}$ & $\begin{array}{c}\text { Kontr } \\
\text { ol }\end{array}$ \\
\hline Jml & 523 & 541 & 582 & 558 \\
\hline $\begin{array}{l}\text { Rata- } \\
\text { rata }\end{array}$ & 26,15 & 27,05 & 29,1 & 27,9 \\
\hline SD & 3,20 & 3,50 & 3,95 & 4,09 \\
\hline Min & 21 & 22 & 24 & 22 \\
\hline Max & 33 & 33 & 39 & 37 \\
\hline
\end{tabular}

Berdasarkan Tabel 4.1. diperoleh hasil pada pretest eksperimen dengan jumlah 523 , rata-rata 26,15 dan simpangan baku 3,20. Pada pretest kontrol diperoleh jumlah 541, rata-rata 27,05 dan simpangan baku 3,50. Pada posttets eksperimen dengan jumlah 582, rata-rata 29,1 dan simpangan baku 3,95. Sedangakan pada posttets kontrol diperoleh jumlah 558, rata-rata 27,9 dan simpangan baku 4,09.

\section{Uji Asumsi}

Setelah nilai rata-rata dan simpangan baku kedua kelompok sampel diketahui, maka langkah selanjutnya adalah melakukan uji normalitas dari data hasil tes tersebut dengan menggunakan uji kenormalan Kolmogorovswirnov. Hasil dari pengujian tersebut dapat dilihat dalam Tabel 4.2. berikut ini: 
Tabel 4.2 Hasil Uji Normalitas Data

\begin{tabular}{|l|c|c|c|}
\hline & $\begin{array}{l}\text { Kolmogor } \\
\text { ov- } \\
\text { Smirnov }\end{array}$ & $\begin{array}{l}\text { Signifika } \\
\text { nsi }\end{array}$ & $\begin{array}{l}\text { Keterang } \\
\text { an }\end{array}$ \\
\hline $\begin{array}{l}\text { Pretest } \\
\text { Eksperim } \\
\text { en }\end{array}$ & 0,754 & 0,620 & Normal \\
\hline $\begin{array}{l}\text { Pretest } \\
\text { Kontrol }\end{array}$ & 0,542 & 0,930 & Normal \\
\hline $\begin{array}{l}\text { Posttest } \\
\text { Eksperim } \\
\text { en }\end{array}$ & 0,715 & 0,687 & Normal \\
\hline $\begin{array}{l}\text { Posttest } \\
\text { Kontrol }\end{array}$ & 0,581 & 0,889 & Normal \\
\hline $\begin{array}{l}\text { Gain } \\
\text { Eksperim } \\
\text { en }\end{array}$ & 0,925 & 0,359 & Normal \\
\hline $\begin{array}{l}\text { Gain } \\
\text { Kotrol }\end{array}$ & 1,220 & 0,102 & Normal \\
\hline
\end{tabular}

Data dinyatakan berdistribusi normal apabila nilai signifikansi (sig) $>0,05$. Pada data pretest eksperimen nilai kormogorov smirnov $(\mathrm{KS})=$ 0,754 dan signifikasi $(\mathrm{sig})=0,620>0,05$. Pada pretest kelompok kontrol $\mathrm{KS}=0,542$ dan sig $=$ $0,930>0,05$. Pada data posttest pada kelompok eksperimen $\mathrm{KS}=0,715$ dan sig $=0,687>0,05$. Pada posttest kelompok kontrol $\mathrm{KS}=0,581$ dengan sig $=0,889>0,05$. Sedangkan selisih (Gain Skor) kelompok eksperimen KS $=0,925$ dan sig $=0,359>0,05$. Pada data gain kelompok kontrol KS $=1,220$ dan sig $=0,102>$ 0,05 . Dengan begitu dapat dinyatakan bahwa seluruh data berdistribusi normal. Uji asumsi selanjutnya yaitu uji homogenitas data. Dalam penelitian ini uji homogenitas data menggunakan uji varians atau levene test. Hasil pengujian homogenitas dapat dilihat pada Tabel 4.3. di bawah ini:

Tabel 4.3. Hasil Uji Homogenitas Data

\begin{tabular}{|l|c|c|c|}
\hline & $\begin{array}{c}\text { t } \\
\text { hitung }\end{array}$ & $\begin{array}{c}\text { Signifik } \\
\text { ansi }\end{array}$ & Keputusan \\
\hline $\begin{array}{l}\text { Permainan } \\
\text { Tradisioanal }\end{array}$ & 4,712 & 0,000 & Pengaruh Signifikan \\
\hline $\begin{array}{l}\text { Permainan } \\
\text { Konvensional }\end{array}$ & 2,001 & 0,060 & $\begin{array}{c}\text { Pengaruh Tidak } \\
\text { Signifikan }\end{array}$ \\
\hline $\begin{array}{l}\text { Perbandingan } \\
\text { Pengaruh }\end{array}$ & 2,776 & 0,008 & $\begin{array}{c}\text { Perbedaan } \\
\text { Signifikan }\end{array}$ \\
\hline
\end{tabular}

Data homogen apabila nilai signifikansi (sig) > 0,05 . Tabel 4.3. menunjukan data pretest memiliki nilai leven statistik $=0,363$ dan Sig $=$ $0,550>0,05$. Data posttet memiliki nilai leven statistik $=0,140$ dan $\mathrm{Sig}=0,711>0,05$. Sedangkan pada data gain skor menunjukan nilai leven statistik $=0,439$ dan $\mathrm{Sig}=0,528>$ 0,05 . Seluruh data memiliki nilai sig $>0,05$ maka dapat diartikan seluruh data bersifat homogen.

\section{Uji Hipotesis}

Uji hipotesis dalam penelitian ini menggunakan uji paired sampel t test dan uji independent sampel $t$ test. Uji paired sampel $t$ test digunakan untuk menguji pengaruh dari perlakuan yang diberikan kepada masingmasing kelompok sampel. Sedangka uji idependent sampel $t$ test digunakan untuk menganalisis perbandingan atau perbedaan antara pengaruh yang diberiakan pada kedua kelompok sampel penelitian.

\section{Tabel 4.4. Ringkasan Hasil Uji Hipotesis 1} (Kelompok Eksperimen)

\begin{tabular}{|l|c|c|c|}
\hline & $\begin{array}{c}\text { Levene } \\
\text { Statistic }\end{array}$ & Sig. & Keterangan \\
\hline Data Pretest & 0,363 & 0,550 & Homogen \\
\hline Data Posttest & 0,140 & 0,711 & Homogen \\
\hline $\begin{array}{l}\text { Data Gain } \\
\text { Skor }\end{array}$ & 0,439 & 0,528 & Homogen \\
\hline
\end{tabular}

Berdasarkan Tabel 4.4. menunjukan untuk pengaruh permainan tradisonal kaulinan barudak terhadap kemampuan mengelola emosi diri sendiri anak usia 5-6 tahun menunjukan nilai $\mathrm{t}=4,712$ dan sig $=0,000<$ 0,05. Dapat diartikan bahwa terdapat pegaruh yang signifikan permainan tradisonal kaulinan barudak terhadap kemampuan mengelola emosi diri sendiri anak usia 5-6 tahun. Pada pengaruh permainan konvensional terhadap kemampuan mengelola emosi diri sendiri anak usia 5-6 tahun menunjukan nilai $\mathrm{t}=2,001$ dan sig $=0,060>0,05$. Artinya tidak terdapat pengaruh yang signifikan penerapan permainan konvensional terhadap kemampuan mengelola emosi diri sendiri anak usia 5-6 
tahun. Sedangakan pada tabel perbandingan pengaruh diperoleh nilai $\mathrm{t}=2,776$ dan sig $=$ 0,008 . Maka dapat diartikan bahwa terdapat perbedaan pengaruh yang signifikan antara penerapan permainan tradisonal kaulinan barudak dengan permainan konvensional terhadap kemampuan mengelola emosi diri sendiri anak usia 5-6 tahun. Dimana permainan tradisioal kaulinan barudak memberikan pengaruh yang lebih signifikan dibandingkan dengan permainan konvensional dalam meningkatkan kemampuan mengelola emosi diri sendiri anak usia 5-6 tahun.

\section{Perbedaan Pengaruh Permainan Tradisional Kaulinan Barudak Dengan Permainan Konvensional Terhadap Pengembangan Kemampuan Mengelola Emosi Diri Sendiri Anak Usia 5-6 Tahun}

Menurut Yusuf (2012) mengatakan bahwa anak usia dini merupakan individu yang berada pada posisi usia perkembangan yang sangat pesat jika dibandingkan dengan masa-masa usia perkembangan lainnya. Usia tersebut dikenal dengan istilah Golden Age atau masa usia emas. Masa usia emas ini maksudnya adalah masa penerimaan dan pengolahan informasi yang dapat dilakukan secara cepat dan tahan lama oleh setiap individu (Hurlock, 1980; Santrock, 2007, Nurihsan \& Agustin, 2011; dan Yusuf, 2012). Oleh karena itu dalam masa usia emas ini merupakan kesempatan yang teramat baik untuk mengoptimalkan perkembangan anak, termasuk dalam hal pengambangan kemampuan pengelolaan emosi diri sendiri anak usia 5-6 tahun. Dalam hal ini permainan tradisional terbukti mampu memberika dampak yang lebih signifikan dari pada permainan konvensional.

Mengenai permainan tradisional kaulinan barudak Iswinarti (2010) menyatakan bahwa permainan tradisional cenderung lebih menekankan pada proses perkembangan kognitif, motorik kasar, motorik halus, sosial, emosional, dan bahasa anak. Selain itu, permainan tradisional dapat mendidik anak melalui aturan-aturan yang telah disepakati bersama. Tidak seperti halnya permainan konvensional yang pada umumnya peraturan permainan sudah menjadi peraturan baku. Heidemann \& Hewit dalam Dahlan (2010: hlm 102) menjelaskan bahwa kesepakatan peraturan dalam suatu permainan itu perlu di adakan, dengan adanya aturan yang disepakati dalam permainan dapat membantu sportifitas para pemain dalam teknis batasan-batasan permainan sehingga akan mencegah terjadinya konflik maupun pertengkaran atas perbedaan persepsi terhadap teknis permainan itu sendiri. Dengan peraturan yang dibuat dan disepakati bersama menimbulkan perasaan saling memiliki dan menjaga peraturan dengan cara mengikuti peraturan permainan sesuai dengan kesepakatan yang telah disepakati bersama.

Selain itu hasil penelitian yang telah dilakukan oleh Syaodih dan Agustin (2013) tentang penerapan permainan tradisional "kaulinan barudak" untuk mengembangkan nilai karakter anak, menyatakan bahwa permainan tradisional "kaulinan barudak" dapat mengembangkan nilai karakter anak usia dini. Sehingga terdapat unsur-unsur yang memberikan stimulus untuk mengembangkan potensi anak usia dini secara positif dan layak dinyatakan sebagai permainan edukatif permainan tradisional "kaulinan barudak". Hasil penelitian tersebut mendukung pada hasil penelitian ini, bahwasannya permainan tradisional memberikan dampak positif yang signifikan pada perkembangan kemampuan emosi diri sendiri anak usia 5-6 tahun.

\section{KESIMPULAN DAN SARAN}

Berdasarkan hasil pengolahan dan analisis data yang telah dilakukan, dapat ditarik kesimpulan bahwa permainan tradisional kaulinan barudak memberikan pengaruh yang lebih signifikan dibandingkan dengan permainan konvensional dalam meningkatkan kemampuan mengelola emosi diri sendiri anak usia 5-6 tahun.

\section{DAFTAR PUSTAKA}

Creswell, J. W. (2010). Research Design; Pendekatan Kualitatif, Kuantitatif, dan Mixed. Terjemahan Achmad Fawaid, et.al. Jogjakarta: Pustaka Pelajar.

Dahlan, T. (2010). Games Sains Kreatif \& Menyenangkan untuk Meningkatkan 
Potensi dan Kecerdasan Anak.

Bandung: Ruang Kata.

Gandana, G. (2015). Meningkatkan

Kecerdasan Emosional Anak Usia Dini

melalui Permainan Tradisional

"Kaulinan Barudak". Tesis: SPs

Universitas Pendidikan Indonesia.

Geldard, K. \& Geldard, D. (2012). Konseling Anak-Anak. Jakarta: Indeks.

Hurlock, E. B. (1980). Psikologi Perkembangan. Jakarta: Erlangga.

Iswinarti. (2010). Nilai-Nilai Terapeutik Permainan Tradisional Engklek Untuk Anak Usia Sekolah Dasar. Naskah Publikasi Penelitian Dasar Keilmuan. Fakultas Psikologi: Universitas Muhammadiyah Malang: Malang.

Nurhidayah, R. E. (2006). Pentingnya Kecerdasan Emosional bagi Perawat: Jurnal Keperawatan Rufaidah Sumatra Utara, 2 (1), 39-42.

Nurihsan, A. J. \& Agustin, M. (2011). Dinamika Perkembangan Anak dan Remaja. Bandung: Refika Aditama.

Rakhmat, C. Budiman, N.; \& Herawati, N. I. (2008). Psikologi Pendidikan. Bandung: UPI Press.

Santrock, J. W. (2007). Perkembangan Anak. Jakarta: Erlangga.

Sujiono, Y. N. (2009). Konsep Dasar Pendidikan Anak Usia Dini. Jakarta: Indeks.

Syaodih, E. dan Agustin, M. (2013). Penelitian Bidang Keilmuan: Penerapan Permainan Tradisional "Kaulinan Barudak" untuk mengembangkan Nilai Karakter Anak. Bandung: UPI.

Undang-Undang Nomor 20 Tahun 2003. Sistem Pendidikan Nasional.

Vakola, M., Tsaousis, I. \& Nikolaou, I. (2004). The Role of Emotional Intelligence and Personality Variables on Attitudes Toward Organisational Change: Journal of Managerialn Psychology, 19 (2), 88110.

Yusuf. LN., S. (2012). Psikologi Perkembangan Anak \& Remaja. Bandung: Remaja Rosdakarya. 